\title{
Research on Comprehensive Evaluation of Service Quality of Distribution Network Construction Unit Based on Analytic Hierarchy Process
}

\author{
Xue Chen ${ }^{1, *}$, Dacai Chen ${ }^{1}$, Jiyu Li ${ }^{1}$, Yifu Lin ${ }^{1}$, Jutian Lai ${ }^{1}$ \\ ${ }^{1}$ State Grid Fujian Electric Power Co.,Ltd.economic and Technological Research Institute, Fuzhou, Fujian Province, China
}

\begin{abstract}
The service quality level of the construction unit plays an important role in improving the construction quality of the distribution network and the operating efficiency of the power grid enterprises. Therefore, this article combines the characteristics of the construction process management of the distribution network, aims to improve the service quality level of the construction unit, and combines the relevant system requirements of the power grid enterprise and the construction standardization management norms to construct a scientific and reasonable evaluation index system for the service quality level of the construction unit; The analytic hierarchy process determines the index weights and evaluation methods, and provides technical guidance and reference for the power grid enterprises to reasonably carry out the service quality evaluation of the construction unit.
\end{abstract}

\section{Introduction}

The construction and transformation of the distribution network is an important public infrastructure guarantee in the decisive stage of the country's grand goal of building a well-off society in an all-round way ${ }^{[1]}$. As an important part of the power system of power grid enterprises, the distribution network is not only the end of the grid, but also the front end of the service. The total amount of assets and the large number of people engaged in distribution network operation services internally affect the company's safe production and corporate benefits. The main link externally represents the company's image and level of serving economic and social development, and its role and status are extremely important and prominent. For a long time in history, there has been a tendency of "emphasis on the main network, light distribution network, equipment, and service". Many contradictions and problems that are uncoordinated and unsuitable have been formed in the management of the distribution network. In recent years, with the gradual increase in the scale of investment in the distribution network, the construction and management of the distribution network has gradually been paid attention to. Due to the current severe internal and external operating situation, severe challenges have been put forward to the level of input and output and the level of refined management in the construction of the distribution network $^{[2]}$. In the future, we must continue to strengthen the standardization and standardized management mode of distribution network construction, and improve the quality, efficiency and benefit of distribution network project construction. There are still many problems in the current distribution network construction management: First, due to the large number of construction projects, the variety of types, and the wide range of coverage, the distribution network construction management, construction and supervision staffing may not match the project construction scale ${ }^{[3]}$. Thus restricting the development of the standardization level and lean management level of the distribution network construction. Second, in some areas, the same person supports the construction and management of multiple projects at the same time, which makes it difficult to achieve the goal of full coverage management. The third is that the "three departments and two generations" management personnel have unclear responsibilities and poor performance of responsibilities, which makes the safety and quality of the project have potential risks ${ }^{[4]}$.

\section{Construction of Service Quality Evaluation Index System for Construction Units}

\subsection{Ideas for constructing evaluation indicators}

In order to scientifically and reasonably evaluate the service quality level of the construction unit, the service quality evaluation index database of the construction unit is constructed based on the power grid enterprise

*Corresponding author's e-mail: 1182306191@ncepu.edu.cn 
distribution network management system and construction standardization management norms, combined with the construction characteristics of the distribution network project and the management needs of the construction unit; Then combined with the principal component analysis method and the optimal judgment matrix method, the evaluation index library was reduced and screened, and the construction unit was constructed from the five aspects of comprehensive representativeness, measurability, comparability, substitutability, and comprehensive guidance. The service quality evaluation index system is combined with the analytic hierarchy process to determine the weight of the evaluation index; finally, the corresponding analysis conclusion is drawn by calculating the comprehensive score of the service quality of the construction unit. The specific research ideas of this paper are shown in Figure 1 below:

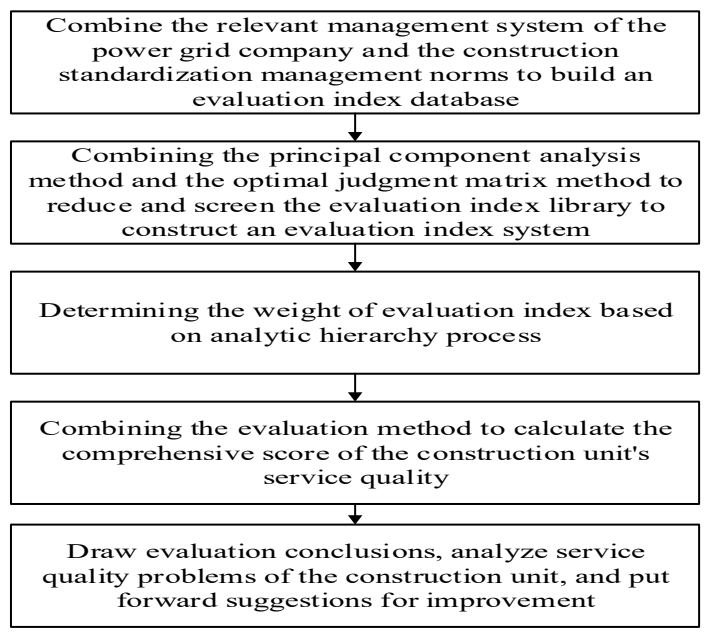

Figure 1. Construction service quality evaluation and analysis ideas.

\subsection{Evaluation index library construction}

The construction unit's service quality evaluation index index library indexes, mainly from the dimensions of the construction project department staffing, the distribution network project process management and other dimensions, the bearing capacity index design, focusing on the construction unit's performance in the quality, schedule, and cost of the distribution network project . The construction of the construction service quality evaluation index database is shown in the following table:

Table 1. Service quality evaluation index library of construction unit.

\begin{tabular}{|c|c|c|c|}
\hline $\begin{array}{c}\text { Serial } \\
\text { number }\end{array}$ & $\begin{array}{c}\text { First-level } \\
\text { index }\end{array}$ & $\begin{array}{c}\text { Secondary } \\
\text { indicators }\end{array}$ & $\begin{array}{c}\text { Three-level } \\
\text { indicators }\end{array}$ \\
\hline 1 & $\begin{array}{c}\text { Construction } \\
\text { service } \\
\text { quality level }\end{array}$ & $\begin{array}{c}\text { Staffing } \\
\text { level }\end{array}$ & $\begin{array}{c}\text { Investment } \\
\text { scale and staff } \\
\text { standard } \\
\text { support ratio }\end{array}$ \\
\hline
\end{tabular}

\begin{tabular}{|c|c|c|}
\hline 2 & & $\begin{array}{c}\text { Project } \\
\text { manager's work } \\
\text { life support } \\
\text { ratio } \\
\end{array}$ \\
\hline 3 & & $\begin{array}{c}\text { Saturation of } \\
\text { qualifications of } \\
\text { project } \\
\text { department } \\
\text { personnel }\end{array}$ \\
\hline 4 & & $\begin{array}{c}\text { Special } \\
\text { operation } \\
\text { certificate } \\
\text { holding rate } \\
\end{array}$ \\
\hline 5 & $\begin{array}{c}\text { Basic } \\
\text { management } \\
\text { level }\end{array}$ & $\begin{array}{c}\text { Quartet meeting } \\
\text { rate }\end{array}$ \\
\hline 6 & & $\begin{array}{c}\text { Personal safety } \\
\text { accident }\end{array}$ \\
\hline 7 & $\begin{array}{c}\text { management } \\
\text { level }\end{array}$ & $\begin{array}{c}\text { On-site } \\
\text { construction } \\
\text { violation } \\
\text { deduction index }\end{array}$ \\
\hline 8 & $\begin{array}{c}\text { Progress } \\
\text { management } \\
\text { level }\end{array}$ & $\begin{array}{c}\text { Time rate of } \\
\text { project } \\
\text { settlement } \\
\text { preparation }\end{array}$ \\
\hline 9 & $\begin{array}{c}\text { Quality } \\
\text { management } \\
\text { level }\end{array}$ & $\begin{array}{l}\text { Project price } \\
\text { reduction rate }\end{array}$ \\
\hline 10 & & $\begin{array}{l}\text { Number of } \\
\text { "Quality } \\
\text { Projects" } \\
\text { obtained }\end{array}$ \\
\hline 11 & $\begin{array}{l}\text { Excellent } \\
\text { management } \\
\text { level }\end{array}$ & $\begin{array}{c}\text { Number of } \\
\text { establishments } \\
\text { of } \\
\text { up-to-standard } \\
\text { excellent } \\
\text { projects }\end{array}$ \\
\hline 12 & Social & $\begin{array}{c}\text { Project } \\
\text { complaint rate }\end{array}$ \\
\hline 13 & impact & $\begin{array}{l}\text { Number of } \\
\text { incidents }\end{array}$ \\
\hline
\end{tabular}

\subsection{Determination of comprehensive evaluation results}

The linear model is selected to summarize the normalized index values of each index, and a comprehensive score is obtained:

$$
\begin{gathered}
y=\sum_{j=1}^{m} w_{j} a_{j} \\
\sum_{j=1}^{m} w_{j}=1,0 \leq w_{j} \leq 1, j=1,2 \cdots m
\end{gathered}
$$

$\mathrm{y}$ is the comprehensive score value of the system, $a_{j}$ is the normalized index value, and $w_{j}$ is the weight coefficient.

\section{Determination of index weight based on analytic hierarchy process}

The Analytic Hierarchy Process (AHP) is a decision-making analysis method that combines 
qualitative and quantitative methods to solve complex problems with multiple goals, which was proposed by Professor T.L.Saaty of the University of Pittsburgh in the 1970s. This method expresses and deals with people's subjective judgments in quantitative form. It is an effective multi-criteria decision-making method. It is also the most common method of subjective weighting. It is also an effective method for people to objectively describe subjective judgments. . It takes a multi-level and multi-attribute index factor optimization decision-making problem for a complex scheme. It obtains the optimal scheme through quantitative calculation through hierarchical serialization and factor importance judgment. It is a multi-objective decision-making technology that can effectively compensate for the traditional Insufficient modeling methods. It can better deal with qualitative factors. Combined with the related theories of the analytic hierarchy process, the service quality evaluation index weights of the construction unit are determined as shown in Table 2:

Table 2. Determination of indicator weights.

\begin{tabular}{|c|c|c|c|}
\hline $\begin{array}{c}\text { Serial } \\
\text { number }\end{array}$ & $\begin{array}{l}\text { First-level } \\
\text { index }\end{array}$ & $\begin{array}{l}\text { Secondary } \\
\text { indicators }\end{array}$ & Three-level indicators \\
\hline 1 & \multirow{11}{*}{$\begin{array}{l}\text { Construction } \\
\text { service } \\
\text { quality level }\end{array}$} & \multirow{4}{*}{$\begin{array}{c}\text { Staffing } \\
\text { level }(0.30)\end{array}$} & $\begin{array}{c}\text { Investment scale and } \\
\text { staff standard support } \\
\text { ratio } \\
(0.15)\end{array}$ \\
\hline 2 & & & $\begin{array}{l}\text { Project manager's work } \\
\text { life support ratio } \\
(0.05)\end{array}$ \\
\hline 3 & & & $\begin{array}{c}\text { Saturation of } \\
\text { qualifications of } \\
\text { project department } \\
\text { personnel } \\
(0.05)\end{array}$ \\
\hline 4 & & & $\begin{array}{c}\text { Special operation } \\
\text { certificate holding rate } \\
(0.05)\end{array}$ \\
\hline 5 & & $\begin{array}{c}\text { Basic } \\
\text { management } \\
\text { level } \\
(0.15)\end{array}$ & $\begin{array}{l}\text { Quartet meeting rate } \\
\qquad(0.15\end{array}$ \\
\hline 6 & & \multirow{2}{*}{$\begin{array}{c}\text { Safety } \\
\text { management } \\
\text { level } \\
(0.30)\end{array}$} & $\begin{array}{c}\text { Personal safety } \\
\text { accident } \\
(0.15)\end{array}$ \\
\hline 7 & & & $\begin{array}{c}\text { On-site construction } \\
\text { violation deduction } \\
\text { index } \\
(0.15) \\
\end{array}$ \\
\hline 8 & & $\begin{array}{c}\text { Progress } \\
\text { management } \\
\text { level } \\
(0.15)\end{array}$ & $\begin{array}{c}\text { Time rate of project } \\
\text { settlement preparation } \\
(0.15)\end{array}$ \\
\hline 9 & & $\begin{array}{c}\text { Quality } \\
\text { management } \\
\text { level } \\
(0.10)\end{array}$ & $\begin{array}{c}\text { Project price reduction } \\
\text { rate } \\
(0.10)\end{array}$ \\
\hline 10 & & \multirow[b]{2}{*}{$\begin{array}{c}\text { Excellent } \\
\text { management } \\
\text { level }\end{array}$} & $\begin{array}{l}\text { Number of "Quality } \\
\text { Projects" obtained } \\
\text { (Extra points, out of } \\
5 \text { points ) }\end{array}$ \\
\hline 11 & & & $\begin{array}{l}\text { Number of } \\
\text { establishments of } \\
\text { up-to-standard } \\
\text { excellent projects } \\
\text { (Extra points, out of } \\
5 \text { points ) }\end{array}$ \\
\hline
\end{tabular}

\begin{tabular}{|c|c|c|c|}
\hline 12 & & Social & $\begin{array}{c}\text { Project complaint rate } \\
\text { (Minus items, full } \\
\text { score of 5 ) }\end{array}$ \\
\cline { 3 - 4 } 13 & & impact & $\begin{array}{c}\text { Number of incidents } \\
\text { (Minus items, full } \\
\text { score of 5) }\end{array}$ \\
\hline
\end{tabular}

\section{Empirical analysis}

This paper collects the basic data of relevant indicators of F Province Electric Power Co., Ltd. in 2020, and analyzes and evaluates the service quality of the company's construction units. The basic data collection situation is shown in Table 3 below:

Table 3. Basic data table.

\begin{tabular}{|c|c|c|c|}
\hline $\begin{array}{c}\text { Serial } \\
\text { number }\end{array}$ & Three-level indicators & Unit & $\begin{array}{c}\text { Actual } \\
\text { value }\end{array}$ \\
\hline 1 & $\begin{array}{l}\text { Investment scale and staff } \\
\text { standard support ratio }\end{array}$ & $\%$ & 17. 27 \\
\hline 2 & $\begin{array}{l}\text { Project manager's work life } \\
\text { support ratio }\end{array}$ & $\%$ & $69.57 \%$ \\
\hline 3 & $\begin{array}{l}\text { Saturation of qualifications of } \\
\text { project department personnel }\end{array}$ & $\%$ & 18. $19 \%$ \\
\hline 4 & $\begin{array}{l}\text { Special operation certificate } \\
\text { holding rate }\end{array}$ & $\%$ & $82.00 \%$ \\
\hline 5 & Quartet meeting rate & $\%$ & $\begin{array}{c}100.00 \\
\%\end{array}$ \\
\hline 6 & Personal safety accident & Pieces & 0 \\
\hline 7 & $\begin{array}{c}\text { On-site construction violation } \\
\text { deduction index }\end{array}$ & $\%$ & $5.52 \%$ \\
\hline 8 & $\begin{array}{c}\text { Time rate of project settlement } \\
\text { preparation }\end{array}$ & $\%$ & $63.21 \%$ \\
\hline 9 & Project price reduction rate & $\%$ & $10.00 \%$ \\
\hline 10 & $\begin{array}{c}\text { Number of "Quality Projects" } \\
\text { obtained }\end{array}$ & Pieces & 72 \\
\hline 11 & $\begin{array}{c}\text { Number of establishments of } \\
\text { up-to-standard excellent } \\
\text { projects }\end{array}$ & Pieces & 17 \\
\hline 12 & Project complaint rate & $\%$ & $1.27 \%$ \\
\hline 13 & Number of incidents & Pieces & 0 \\
\hline
\end{tabular}

Combining the weighted summation of the comprehensive weights of various indicators, the comprehensive benchmarking score of the corresponding enterprise is finally obtained:

Table 4. Comprehensive evaluation results.

\begin{tabular}{|c|c|c|}
\hline $\begin{array}{c}\text { Serial } \\
\text { number }\end{array}$ & Evaluation goal & $\begin{array}{c}\mathbf{2 0 2 0} \text { total } \\
\text { score }\end{array}$ \\
\hline 1 & $\begin{array}{c}\text { Construction unit service } \\
\text { quality evaluation score }\end{array}$ & 87.82 \\
\hline
\end{tabular}

Through actual evaluation, the scores in 2020 were 87.82 points. The specific analysis conclusions are as follows: 1) In 2020, the investment scale and standard staff support ratio index value is less than 1 , which is $27.09 \%$ and $27.09 \%$, indicating that the company's existing construction project department management staff cannot support the investment scale of the distribution network investment plan that year. 2) In 2020, the four-party review of the construction project department reached $100 \%$, meeting the company's specification requirements. 3) In 2020, there will be no personal safety accidents in the distribution network project, and the safety control measures and control effects of the construction project department have been implemented well. 4) In 2020, the work experience, 
personnel qualification level of the project manager of the construction project department and the certification level of special operation personnel need to be further improved. 5) In 2020, some construction project departments have problems with construction site violations and social complaints. Civilized construction and communication and coordination in the construction process need to be further strengthened. 6) In 2020, the problem of untimely settlement of the construction project department is still serious, and management should be further strengthened, and settlement related materials should be submitted to the owner in a timely manner in strict accordance with the company's specifications. 7) In 2020, the construction project will actively assist the owner to carry out the work of meeting the standards and creating excellence in the distribution network, and has achieved good implementation results.

\section{Conclusion}

Carrying out a comprehensive evaluation and analysis of the service quality of the construction unit can further clarify the problems and weaknesses in the construction management process of the construction unit at this stage, so as to provide decision-making guidance for the power grid enterprises to formulate targeted improvement suggestions. To this end, based on the management characteristics of the distribution network and the standardized construction requirements of the construction project department, this article screens representative and measurable indicators, and builds a comprehensive evaluation index system for the service quality of the construction project department; then combines the analytic hierarchy process to make it clear The weight of each indicator is calculated, and the comprehensive score is calculated by collecting relevant indicator data, so as to obtain the service quality level of the construction project department; finally, combined with empirical analysis, the effectiveness of the method is verified. The application of the comprehensive evaluation method of the service quality of the construction project department plays an important supporting role in improving the lean management level of the distribution network project.

\section{References}

1. Yang Junxin, Wang Lisha, Chen Tielei, Tang Wei, Wen Huajing. Human resource management of substation maintenance enterprise oriented by carrying capacity $[\mathrm{J}]$. Human Resources Development, 2015(20): 81-82.

2. Zhang Chunxiang, Ma Changjiang. Discussion on the control mechanism of subcontractor's carrying capacity limitation $[\mathrm{J}]$. Shandong Industrial Technology, 2019(08):238.

3. Shen Juemin. Analysis of the carrying capacity of the construction management personnel of the power infrastructure project based on the horizontal road map method[J]. Building Materials and Decoration, 2019(11): 235-237.

4. Li Youliang, Chen Cunlin, Zhang Wei, Ye Haifeng, Liu Ludeng. Analysis and Suggestions on the Business Carrying Capacity of Electric Power Company Dispatchers[J]. Electric Power Safety Technology, 2018, 20(05): 17-20.

5. $\mathrm{Xu}$ Mengjie. Analysis of the work carrying capacity of the front-line teams of power supply enterprises[J]. The World of Labor and Social Security (Theoretical Edition), 2013(09):231. 